\title{
Business and Human Rights: A Configurational View of the Antecedents of Human Rights Infringements by Emerging Market Firms
}

\author{
Luciano Ciravegna $^{1,2} \cdot$ Federica Nieri ${ }^{3}$
}

Received: 9 November 2020 / Accepted: 2 June 2021 / Published online: 19 June 2021

(c) The Author(s) 2021

\begin{abstract}
This study investigates the antecedents of human rights infringements (HRIs) by emerging market firms (EFs). We used fuzzy set qualitative comparative analysis (fsQCA) to examine HRIs in 245 firms based in eight emerging markets, between 2003 and 2012. Our findings disclose three equifinal configurations of high levels of HRIs, all involving EFs that have expanded to a high number of foreign markets: (i) large, old, low performing state-owned enterprises (SOEs) operating in high quality institutions' home and host markets, (ii) small, young, over-performing EFs operating in low quality institutions' home and host markets, and finally (iii) large, old, high performing SOEs, operating in low quality institutions' home and host markets. We contribute to the literature by examining a novel dataset on HRIs by EFs, and by building a configurational explanation of HRIs that bridges the arguments of the institutional theory and strain theory literatures on corporate wrongdoing.
\end{abstract}

Keywords Business and human rights $\cdot$ Human rights infringements (HRIs) $\cdot$ Emerging market firms (EFs) $\cdot$ Multinational corporations (MNCs) · Fuzzy sets qualitative comparative analysis (fsQCA)

\section{Introduction}

There is a growing interest in the business ethics and management literatures to understand how the business sector addresses "grand challenges" regarding sustainability (Ferraro et al., 2015; Hamann et al., 2020). One such grand challenge is to address human rights infringements (HRIs) (Baumann-Pauly et al., 2017; Wettstein et al., 2019), which are defined as the business-related violation of one of the entire range of human rights detailed in the 1948 Universal Declaration of Human Rights and subsequent covenants and treaties (Fasterling \& Demuijnck, 2013; Wettstein, 2012). ${ }^{1}$ Examples of HRIs include different types of labor rights abuses, such as child labor, labor discrimination, and union

Federica Nieri

federica.nieri@unipi.it

Luciano Ciravegna

luciano.ciravegna@incae.edu

INCAE Business School, La Garita, Costa Rica

2 Henley Business School, Reading University, Reading, UK

3 Responsible Management Research Center, Department of Economics \& Management, University of Pisa, Pisa, Italy busting. HRIs also include violations of the rights to land and life perpetrated against indigenous communities to gain access to natural resources, and instances where business conduct causes harm to people, such as when business facilities contaminate freshwater sources and farmland (Schrempf-Stirling \& Wettstein, 2017). The role of business regarding the human rights debate has become more salient since the United Nations (UN) launched the UN Guiding Principles on Business and Human Rights (United Nations, 2011), an influential soft law initiative inspired by the 1948 Universal Declaration of Human Rights (Bernaz, 2016; González-Cantón et al., 2019).

In this study we seek to enhance our understanding of this issue by addressing the following question: What are the antecedents of emerging market firms' human rights infringements? While scholars before us have asked why firms engage in behavior with harmful consequences for society (e.g., Armstrong, 1977; Greve et al., 2010; Palmer et al., 2016; Staw \& Szwajkowski, 1975; Vernon, 1977),

\footnotetext{
${ }^{1}$ Examples of such covenants and treaties are the International Covenant on Civil and Political Rights, the International Convention on Economic, Social, and Cultural Rights, and the eight fundamental conventions of the International Labor Organization as set out in the International Labor Organization Declaration on Fundamental Principles and Rights at Work.
} 
the extant business and human rights literature has thus far focused mostly on the conceptual, ethical, legal, and normative dimensions of the phenomenon (Buhmann, 2017; González-Cantón et al., 2019; Sjåfjell, 2020; Van Buren III et al., 2021). Empirical research on the causes of business infringements of human rights is still incipient, and mostly focuses on specific events or contexts, partly due to the difficulty of gathering information on such events (Maher et al., 2021; Nieri \& Giuliani, 2018; Olsen et al., 2020). For instance, some studies focus on a specific industry, such as Maher's (2020) discussion of human rights controversies in mining, or on a firm's operation, such as Whiteman and Cooper's (2016) in-depth study of rape cases linked to the operations of a Malaysian forestry firm in Guyana. Other studies have discussed specific types of HRIs, such as businesses using forced labor (Crane, 2013; Kolk \& Van Tulder, 2004) or abusing indigenous communities' rights (Calvano, 2008). We address this gap in the literature by using a novel database covering multiple industries, firms, years, and markets.

A further research gap in HRIs studies is that most of the debate revolves around abuses committed by corporations headquartered in advanced markets (Palmer et al., 2016). Although emerging market firms (EFs) account for a growing share of the world's trade and foreign investment, these firms have been under the radar in the business and human rights debate (Wettstein et al., 2019). In this paper we examine, to our knowledge for the first time, the antecedents of business involvement in HRIs for EFs.

We develop our theoretical framework drawing on the literature covering the dark side of management (e.g., Greve et al., 2010; Palmer et al., 2016). Most of this literature does not refer explicitly to HRIs, instead using broader categories that include HRIs as a subset representing the most severe form of these kinds of harmful conduct, such as "corporate wrongdoing" (e.g., Palmer, 2012), "corporate irresponsibility" (e.g., Strike et al., 2006), "corporate misconduct" (e.g., Greve et al., 2010), and "deviant organizational practices" (e.g., Vaughan, 1999). ${ }^{2}$ This disparate literature has a

\footnotetext{
${ }^{2}$ We checked all the definitions of terms mentioned here, and verified that HRIs, as the 1948 Universal Declaration of Human Rights defines them, are a subset of corporate wrongdoing, corporate misconduct, corporate social irresponsibility, and deviant organizational practices. We focus on HRIs, which are the most severe form of the conducts discussed in the literature on the dark side of management. We acknowledge that not all corporate wrongdoing, corporate misconduct, corporate irresponsibility, and deviant organizational practices amount to HRIs, because they also include milder forms of harm to society, such as tax evasion, which do not infringe human rights. Nonetheless, in the absence of clearer empirical evidence, the causal mechanisms explored in the literature on management's dark side provide a solid theoretical grounding for our study of such causal mechanisms specific to HRIs.
}

common theme in considering the drivers of business conduct that has harmful consequences for society. For parsimony, we will use only the terms "corporate wrongdoing" and "HRI".

Research on corporate wrongdoing has evolved along two major literature streams. The first stream focuses on institutions as contextual antecedents, and argues that business involvement in HRIs is more likely in markets where institutions do not perform their roles efficiently, thus where they do not regulate, monitor, and sanction business behavior that has harmful effects on society (Khanna \& Palepu, 1997). Empirical evidence of corporate wrongdoing illustrates that institutions, per se, do not provide a comprehensive explanation - unfortunately, businesses do get involved in corporate wrongdoing, including HRIs, in high quality institutions markets. A second research stream on corporate wrongdoing, anchored in strain theory (Merton, 1938), suggests that firms get involved in corporate wrongdoing (including HRIs) because of different types of resource constraints. There are, however, conflicting arguments regarding the effect of firmlevel antecedents used to measure resource constraints.

We argue that the debate on HRI drivers is inconclusive because of the scarcity of empirical evidence, in particular on EFs, but also because the causal factors recognized in the different research streams combine in a causal conjectural manner, generating multiple, asymmetric causal paths linked to this phenomenon of HRIs. We address this evidence gap by studying the antecedents of EFs' involvement in HRIs from a configurational perspective. Prior research has not considered the inherent causal complexity associated with how drivers belonging to the institutional context where firms operate, as well as firm-level characteristics, can simultaneously be interdependent in how they influence firms' involvement in HRIs. To investigate these interdependencies, we use fuzzy set qualitative comparative analysis (fsQCA). This is an approach that can give insight into how HRI antecedents identified in the extant literature combine and interact in configurations that are equifinally linked to the outcome (Misangyi et al., 2017; Ragin, 2008; Verbeke et al., 2019). Although none of the antecedents, per se, might be sufficient for HRIs to occur, in a given context they can interact to give rise to such HRIs. In this study, our goal is to identify these causal paths and unravel how internal and external factors together affect firms' involvement in HRIs.

Our study contributes to the literature in three ways. First, we advance research on HRI drivers from an empirical perspective, using a novel database covering multiple industries, firms, years, and markets. Second, we examine HRIs in EFs, thereby addressing the scarcity of empirical work on these firms regarding human rights. Third, this is, to our knowledge, the first attempt to study the antecedents of business-related HRIs using a configurational and equifinal causal logic. Our configurational perspective allows us to 
bridge different arguments from the literature on corporate wrongdoing, and explore how theory grounded antecedents interact with each other, generating unique situations in which firms get involved in HRIs. We illustrate that the drivers of corporate wrongdoing identified by the literature anchored in strain theory are contingent to the institutional context in which firms operate. For example, we find that being smaller and younger are important antecedents of HRIs for businesses that are not state owned, if the latter also operating in low quality institutions markets, where sanctions against firms committing HRIs are less severe and less likely to be enforced.

We argue that it is not only institutional factors to provide boundary conditions to the impact of firm-level antecedents on HRIs - the way in which institutional incentives shape business involvement in HRIs is also contingent on firmlevel factors. By combining these two theoretical traditions, we provide a more nuanced and realistic explanation of the situations in which firms get involved in HRIs. We believe that this contribution has implications beyond HRIs: our study illustrates the importance of examining the interactions between institutions and firm-level factors when trying to interpret business conduct.

The rest of the paper is organized as follows. First, we review the literature to highlight the causal conditions to be included in the empirical analysis. Next, we set out the context for the study which we investigate using fsQCA. We conclude by discussing our findings' implications for research and practices.

\section{Theoretical Framework}

\section{Institutions and Human Rights Infringements}

Studies of business and human rights emphasize the role of national institutions in regulating business conduct and exerting pressure on business to prevent involvement in human rights abuses (Mena et al., 2010; Wettstein, 2010). There are several mechanisms through which institutional pressures influence business involvement in HRIs. Overcomplex regulations can create ambiguity regarding what constitutes an HRI (Wettstein, 2009). An inefficient, underresourced, and unaccountable judiciary, and high levels of corruption reduce the likelihood of corporate wrongdoing being sanctioned (Keig et al., 2015; Spencer \& Gomez, 2011). Both home and host market institutions shape business conduct, as we discuss in the following sections.

\section{Home Market Institutions}

Home market institutions influence firm-level behavior, including their strategy (Meyer \& Peng, 2016) and incentives to respect human rights (Whelan \& Muthuri, 2017). Some scholars argue that low quality institutions result in "institutional voids" (Brenes et al., 2019; Khanna \& Palepu, 1997), i.e., situations in which institutions fail to perform their functions, which would include sanctioning businesses' involvement in HRIs. Being based in a high quality institutions home market entails a higher likelihood of being apprehended for HRIs, and more severe sanctions for firms found guilty of HRIs (Keig et al., 2015; Spencer \& Gomez, 2011; Yiu et al., 2014). In contrast, firms based in low quality institutions home markets can learn how to thrive in such environments (Cuervo-Cazurra et al., 2018), for example relying on corruption to alleviate the negative consequences of involvement in HRIs. Therefore, firms operating in home markets with higher quality institutions should be less likely to commit HRIs because being implicated in human rights abuses could damage their legitimacy vis-a-vis domestic stakeholders, in particular consumers and investors (Baumann-Pauly et al., 2017; Surroca et al., 2013).

\section{Internationalization}

Internationalization creates further challenges and makes the effect of institutions more difficult to grasp. On the one hand, the more diverse the set of markets in which a firm operates, the higher the challenge of monitoring compliance with regulations and also, more broadly, of having foreign subsidiaries' oversight that can assist in preventing HRIs (Kostova \& Roth, 2002; Strike et al., 2006). On the other hand, internationalization can create incentives for refraining from HRIs, as EFs try to overcome their liability of origin and gain an international reputation by signalling good conduct (Fiaschi et al., 2015; Marano et al., 2017; Zyglidopoulos et al., 2016).

\section{Host Market Institutions}

In line with the old adage "When in Rome, do as the Romans," firms adapt to institutional contexts, mimicking the behavior of local organizations (DiMaggio \& Powell, 1983; Salomon \& Wu, 2012). Accordingly, business with operations in low quality institutions' host markets would be more likely to engage in HRIs, even if these firms are based in high quality institutions' home markets (Surroca et al., 2013). Conversely, EFs that have internationalized in high quality institutions' host markets face strong institutional pressure to avoid involvement in HRIs (Fiaschi et al., 2017; Zyglidopoulos et al., 2016). In sum, EFs operating in high quality host market institutions should be less likely to commit HRIs because, (a) they respond to incentives to gain legitimacy with international stakeholders (Fiaschi et al., 2017; Jackson et al., 2020; Marano et al., 2017; Zyglidopoulos et al., 2016), (b) they engage in mimetic behavior, 
i.e., they emulate other firms' conduct in these host markets (Spencer \& Gomez, 2011), and (c) there is a higher likelihood of being sanctioned and more severe implications for HRIs than otherwise (Keig et al., 2015; Yiu et al., 2014). Yet, unfortunately, there are many cases of firms in high quality host market institutions that commit HRIs, which illustrates that the institution's market situation per se is an insufficient explanation of business involvement in HRIs. For these reasons we examine how institutional pressure, both at home and in host market, and internationalization interact with firm level, theory-grounded antecedents.

\section{Firms' Resources and Human Rights Infringements}

Strain theory, which has been foundational in the literature on corporate wrongdoing, identified resource constraints as a key driver of business conduct (e.g., Baucus \& Near, 1991; Staw \& Szwajkowski, 1975). The main logic is that firms can fail to prevent HRIs because they lack the necessary organizational resources to support proper human rights observance. We refer to four antecedents that capture different dimensions of such resource constraints that in complex ways could be linked to HRIs: firm performance (which indicates whether the firm is facing resource constraints in a specific period), size (a proxy for firm resources), age (a proxy for organizational experience), and state ownership (which can provide the firm with extra resources, such as diplomatic and financial support).

\section{Performance}

Financial pressure has been identified as key driver for firms' involvement in corporate wrongdoing (e.g., Baucus \& Near, 1991; Staw \& Szwajkowski, 1975). Firms purportedly get involved in corporate wrongdoing because they are attempting to improve their performance, for example in recovering from a period of negative performance (Crane, 2013). Mishina et al. (2010) argue that high performing firms can also get involved in performance-related corporate wrongdoing. They suggest that high performance can make managers overconfident and willing to take high risks to maintain their position. However, empirical evidence on these mechanisms remains scarce, and it is difficult to infer what motivates managerial decisions from firm-level data (Bromiley, 2010). As with other antecedents, performance might have different implications depending on whether the firm is a stateowned enterprise (SOE), its size, internationalization, and the institutional pressure to which it is exposed at home and abroad. A firm contemplating HRIs to boost its performance, for example by seizing land from indigenous communities without compensating them, is likely to take into account the potential negative implications of its actions, such as consumer boycotts, investors' reactions, and the cost of legal disputes. All such costs will depend on the quality of the institutions where the firm operates.

\section{Size}

Prior research uses firm size as a proxy for organizational resources, with the initial argument that more resourceful firms should have more means to invest in the prevention of corporate wrongdoing (Martin et al., 2007). Larger firms are more visible, therefore corporate wrongdoing will more likely be detected and prosecuted, which should incentivize investment in HRI prevention (Soundararajan et al., 2018), which could preserve their legitimacy with stakeholders at home and abroad (Ashforth \& Gibbs, 1990). On this basis the opposite causal relationship has also been proposed. Arguably, larger firms can easily absorb the fines accrued by involvement in corporate wrongdoing because they have slack resources, and hence could commit rights infringement in a calculated attempt to profit from it (Clinard \& Yeager, 1980; Yeager, 1986). Alternative arguments are that larger firms have more complex organizational structures, which makes corporate wrongdoing more difficult to prevent (Baucus \& Near, 1991), especially if the firms are also internationalized (Strike et al., 2006).

\section{Age}

Age matters in that younger firms suffer from the "liability of newness" or poor organizational experience (Bruderl \& Schussler, 1990; Mudambi \& Zahra, 2007), which could make their attempts to prevent HRIs ineffective (Tang et al., 2015). Older firms, in contrast, should be better placed to avoid involvement in HRIs (Kelley et al., 1990), because they can learn from past experience (Zahra et al., 2005), which includes their own organizational experience as well as evidence of the consequences of HRIs other firms committed. Age allows for more trial and error and for developing organizational routines to address specific issues, such as routines that minimize the risk of workplace accidents or help to monitor geographically dispersed operations (Campbell, 2007). Further, firms that are both large and old could have more to lose in terms of reputation, and hence would be keen to avoid HRIs.

However, firm size and age could have the opposite effect when combined with other antecedents. Old, large, internationalized firms operating in low quality institutions' markets accumulate organizational experience in navigating corrupt environments (Cuervo-Cazurra et al., 2018), which could mean these firms are less careful about HRIs because they know how to pay their way out with minimal consequences. Young firms with less resources (such as small businesses) might be more dependent on stakeholders like investors, clients, and regulators, in order to acquire 
and maintain legitimacy. This could impel them to be more careful to avoid HRIs.

\section{Ownership: The Role of the State}

Ownership is a key determinant of business behavior, particularly if the state is the owner (Musacchio et al., 2015). That SOEs are prevalent in emerging markets (Zhang et al., 2009), emphasizes the importance of studying the effects of this antecedent. To illustrate, SOE shares in the Forbes Global 2000 companies exceed $50 \%$ for China, India, and Indonesia and are at 39\% and 19\% for Russia and Brazil respectively (Kowalski et al., 2013). State ownership provides firms with extra resources, such as access to credit, subsidies, government contracts, and other forms of support, which, consistent with strain theory, can reduce SOEs' involvement in HRIs and other corporate wrongdoings (Gao \& Yang, 2021).

State ownership also influences the ways in which firms respond to home and host markets' institutional pressures because SOEs are interconnected to home institutions, and the state is their principal stakeholder (Whelan \& Muthuri, 2017). SOEs are deemed to "have legitimacy and receive support or even protection from the government agencies that have founded them" (Li \& Zhang, 2010, p. 794). Being close to the state can create agency issues, and has been shown to have negative effects on the quality of corporate governance (Cheung et al., 2010), e.g., by reducing transparency regarding the firm's conduct (Gul et al., 2010; Stuart \& Wang, 2016).

As with other antecedents, specific interactions can explain contrasting empirical results. If SOEs sanction HRIs it could threaten the home institutions' reputation; for example, the reputation of the agency in charge of monitoring and regulating business could be at stake, and senior public sector officers managing the SOEs could be implicated (Hou $\&$ Moore, 2010). Still, in high quality market institutions the monitoring mechanisms could be insufficient to shield SOEs and their managers from prosecution for HRIs. Additionally, not all SOEs benefit equally from the "insulation" effect that being part of the state might provide regarding the negative externalities of involvement in HRIs. Larger, older SOEs are more likely to recruit politicians for senior management roles, thus featuring high public sector officers' presence in their administrative boards and generating mutually beneficial relationships between state and business. This would enhance the agency issues mentioned above (Hillman, 2005). Younger, smaller SOEs, in contrast, might not be sufficiently entrenched in the home market institutions to benefit from this sort of insulation effect.

In sum, firm size, age, performance, and ownership interact with home and host market institutional quality and internationalization, thereby creating the complex causal situations in which firms get involved in HRIs. For example, being extensively internationalized in diverse settings can make it harder for a firm to avoid HRIs if the firm is also small and young. Different situations could lead highly internationalized firms equifinally to HRIs. We contribute to the debate by studying the ways in which the antecedents that different streams of research on corporate wrongdoing have identified, work in conjunction to form the causal situations of HRI involvement.

\section{Method}

\section{Sample}

Our sample includes the 245 largest publicly traded companies in Brazil, China, India, Malaysia, Mexico, Russia, South Africa, and Thailand according to Forbes Global 2000 (2012 ed.). We selected these markets on the basis of their being among the largest and fastest-growing emerging markets (Marquis \& Raynard, 2015), and home to the largest firms (UNCTAD, 2014). We focused on public firms due to their international status, potentially significant impact on society, and higher likelihood of the press and non-governmental organizations (NGOs) extensively reporting HRIs. Our analysis covers the period 2003-2012, and relies on an unbalanced panel of 2401 firm-year observations.

\section{FsQCA}

To investigate our research question, we used fsQCA, a method particularly appropriate when causation is complex, different conditions can produce identical results, and different theoretical explanations for the same phenomenon are possible (Fiss, 2007; Misangyi et al., 2017), as is the case with the causal antecedents of HRIs in EFs. FsQCA uses set-theoretic logic, based on Boolean algebra, to identify the causal conditions associated with an outcome, and it provides techniques to identify patterns between set membership and outcome (Crilly, 2011). Put differently, fsQCA explicitly casts causal relations along all three lines of complexity highlighted by earlier configurational theories in management, and defines causal complexity as composed of "equifinality, conjunctural causation, and causal asymmetry" (Schneider \& Wagemann, 2012, p. 78). This approach enables us to study how multiple causal attributes combine into distinct configurations to produce an interesting outcome (conjunctural causation), and to assess whether multiple configurations are linked to the same outcome (equifinality), in this case, involvement in HRIs. Management researchers have used fsQCA to study, for instance, consumers' unethical judgments (Leischnig \& Woodside, 2019), board gender diversity (Lewellyn \& Muller-Kahle, 2020), the adoption of 
ethical standards (Prado \& Woodside, 2015), the drivers of high performance (Brenes et al., 2019), institutional diversity (Jackson \& Deeg, 2008), varieties of capitalism (Judge et al., 2014), strategies to manage institutional voids (Brenes et al., 2019), stakeholder and shareholder orientation drivers (Crilly, 2011), and the antecedents of opportunism in market entry (Verbeke et al., 2019).

\section{Calibration}

The first step in performing fsQCA is to calibrate set membership, in order to transform conventional variables into fuzzy membership scores ranging from 0 to 1 . Different to quantitative approaches that treat all variance as equally important, the aim of calibration is to identify meaningful case grouping (Ragin, 2008), which requires substantive knowledge of the cases considered, or a strong theoretical background (Rihoux \& Ragin, 2008). We followed prior research (Ragin, 2000, 2008) and used a three-level scale where 0 represents full non-membership of a set, 1 represents complete membership of a set, 0.5 represents intermediate level membership of a set, where there is a level of maximum ambiguity regarding whether a case is more a part of the set, or less so. Since cases with fuzzy set membership scores of 0.5 cause difficulties when intersecting a fuzzy set, Ragin (2008) recommends we avoid using it. To address this issue, we added a constant of 0.001 to all the variables with fuzzy set membership scores smaller than 1 (Fiss, 2011). For each calibration, we set these thresholds based on extant theory and substantive knowledge, and used the direct method of calibration on the fsQCA software to transform the measures into set membership (Fiss, 2011; Ragin, 2008).

\section{Truth Table}

The second step involves constructing the truth table to identify the combinations of causal conditions associated with the outcome. This is the list of all logically possible combinations. Since we considered seven causal conditions, the truth table produced $2^{7}$ combinations. Given that not all the possible combinations are covered in the firms we considered and to identify those that are relevant, we deleted those not associated with any firms in the dataset. Then, since we considered a big sample of firms, we set the frequency threshold to three, as suggested by Fiss (2011), which allowed us to retain more than $98 \%$ of the cases. We specified the threshold for the consistency which measures the degree to which a combination of causal conditions is reliably associated with the outcome (Ragin, 2008), in our case, the intensity of firms' involvement in HRIs. An efficient consistency threshold can range from 0.75 to 0.95
(Ragin, 2006). We used a very conservative approach, choosing a threshold of 0.95 .

\section{Solutions}

The next step involves an algorithm to generate a more parsimonious understanding of the drivers of firms' involvement in HRIs (for more details, see Ragin, 2008). Then, the fsQCA software produces three solutions (Fiss, 2011): a complex solution (i.e., it produces the most complicated results), an intermediate solution (i.e., it reports results that are a compromise between inclusions of no or any logical reminder in the counterfactual analysis), and a parsimonious solution (i.e., it produces the most concise result since if a causal condition is considered redundant, it is eliminated from the configuration leading to the occurrence of the outcome). Following Fiss (2011), in interpreting the results we considered both the intermediate and the parsimonious solutions to identify the core causal conditions (those identified by both solutions) and the peripheral causal conditions (those that appear in only the intermediate solution) that contribute to the outcome.

\section{Sensitivity Analyses}

We performed a number of sensitivity analyses to examine the stability of our configurations. Following Epstein et al. (2008) suggestion, we replicated the analysis with a frequency threshold of 7,14, and 17, which generated similar solutions. We kept a consistency threshold of 0.95 because it is more precise than lower thresholds (Schneider \& Wagemann, 2006).

\section{Outcome: Human Rights Infringements}

To measure firms' involvement in HRIs, we took several steps. We started by identifying the HRIs in which each of the firms in the sample had been involved in each year. We collected data on the HRIs in which our sample firms were implicated using the Business and Human Rights Resource Centre (BHRRC), the world's leading independent information hub providing data on the positive and negative impacts firms have on human rights (Avery, 2009), and one of the sources most commonly used by international law scholars (Bernaz, 2016; Ruggie, 2008). The BHRRC collects business and human rights news and reports from multiple sources on a daily basis, subject to a minimum credibility criterion (which excludes blind attacks on companies). Since allegations of companies' human rights violations are made public, companies have an opportunity to respond to such imputations before their publication on the BHRRC website. If companies do respond, their counter-arguments are 
published alongside the articles/reports condemning their conduct.

Through the BHRRC we identified instances of businessrelated HRIs linked to our sample firms, which resulted in more than three thousand documents. We analyzed each document, and codified the information into a dataset which includes several pieces of information on each HRI involving firms in our sample. More specifically, for each HRI, we extracted details on the main characteristics of the violation, e.g., 'it exposed employees to radiation without protection, which has resulted in long term illness or death,' the year(s) in which the violation occurred, specifying the year in which it is known to have started, the year in which it is considered to have ceased, and the year in which it was first denounced or reported. After codifying the dataset, we asked a human rights expert experienced in working for BHRRC, to check the cases to ensure no errors or misunderstandings regarding the reported events, and that the violation coding was accurate. This process identified $719 \mathrm{HRI}$ instances involving the firms in our sample, in the cohort 2003-2012.

Next, based on this codification, we identified the number of HRIs in which each firm in our sample had been involved in each year. Every HRI codified in the dataset captured a different infringement in which the firm was involved. Every infringement was annually counted as one, whether it had occurred in one particular year only, or lasted for more than a year, as in a firm violating local residents' right to health by poisoning the environment over several years. In such cases we counted the multi-year infringement as one for each year in which it had occurred. Since we are interested in the intensity of firms' involvement in HRIs, we counted different HRIs by summarizing all the same firm's recorded infringements in each year. Therefore, if in a given year, for instance, a firm was found to abuse workers' rights in one of its plant, and in the same year there was evidence of this firm violating local communities' right to health and safety, the number of HRIs for this firm in the specific year would be two, because the firm had been involved in two human rights violations.

We also cross-checked our coded information from the BHRRC against a "controversy report" produced by Sustainalytics, a different source documenting environmental, social, and governance (ESG) indicators used in prior management research (Surroca et al., 2013). We found that for the period 2009-2012, events BHRRC had reported were also included in the Sustainalytics records, suggesting that our data source is reliable and comprehensive.

After identifying the HRIs in which each firm was involved in each year of the cohort, we dealt with several caveats that could have affected the measurement of firms' involvement in HRIs and other forms of corporate wrongdoing. First, we considered media attention to companies' operations, since the more frequently reports on a firm appear, the more likely the media will find out and report on HRIs in the firm. Therefore, firms less visible in the media, are less likely to be reported for HRIs (Mishina et al., 2010; Zyglidopoulos et al., 2012). Second, some industries, such as extractive industries, are by their very nature more likely to generate harmful impacts than others (Du \& Vieira, 2012; Vadlamannati et al., 2020). Third, considering that we observed companies from 2003 to 2012, we had to bear in mind how the internet and increased global attention impacted attention to the negative business externalities regarding human rights. This, e.g., led NGOs to monitor business operations more strictly, therefore we had to take a time trend in the reporting of HRIs into account.

To account for these caveats, we followed prior research. Building on Fiaschi et al. (2020), we used an M-quantile regression approach which, starting from the data collected on BHRRC, provides an index ranging from 0 to 1 , with 0 and 1 respectively indicating lower and upper boundaries of involvement in HRIs. More specifically, we used this methodology to condition the number of HRI events (as reported by the codification of BHRRC data) in which each firm had been involved in each year, to a set of variables: media exposure, industry dummies, and time dummies. We measured companies' Media Exposure as the logarithm of the number of news articles mentioning each firm in each year (source: NexisUni). Additionally, we accounted for industry characteristics, by grouping firms according to the extent to which an HRI was more or less likely to occur in a given industry (Dougherty \& Olsen, 2014; Wright, 2008). Thus, the reference group (Industry Dummy I) includes firms in the extractive industries (oil, gas, mining, and steel), the second group (Industry Dummy II) includes retail, banking, chemicals, and pharmaceuticals, and the third group (Industry Dummy III) includes cosmetics, pulp and paper, aerospace, automotive, heavy industry, telecommunications (TLC), food and beverages, electricity, real estate, services and electronics sectors. Finally, we considered Time Dummies in order to take into account the time trend in the reported HRI activities.

We applied the M-quantile regression (for detailed information on the model, see "Appendix") to build the outcome variable Human Rights Infringements. This is an index computed for each firm in the sample, for each year in the cohort 2003-2012, by applying the M-quantile regression to gain a measure of their involvement in HRIs taking into account their exposure to the media, the industry to which they belong, and the time trend characterizing the cohort we analyzed. The index ranges from 0 to 1 , with 1 indicating the maximum intensity of involvement in HRIs, and 0 indicating the minimum intensity of involvement in HRIs. "Appendix" also shows the results of the M-quantile regression.

\footnotetext{
${ }^{3}$ Since the Human Rights Infringements index ranges from 0 to 1 , we do not have to calibrate this variable to run fsQCA.
} 


\section{Causal Antecedents}

According to our theoretical framework, we included seven causal antecedents in the analysis. Table 1 summarizes how we treated such variables (and the two variables used to condition our outcome, namely media exposure and industry) in our empirical analysis, and the literature justifying our choices.

\section{Home Market Institutions}

To measure the quality of home market institutions we built a meta-index of the six Worldwide Governance Indicators (WGI), namely voice and accountability, political stability and absence of violence, government effectiveness, regulatory quality, rule of law, and control of corruption. ${ }^{4}$ The World Bank developed these indicators by aggregating several hundred individual variables drawn from 31 data sources collected by 25 organizations (Kaufmann et al., 2011). Because the six WGI are highly correlated, we followed prior research (Marano et al., 2017) in developing an index estimated from the first principal components of the six indicators. Since we have considered only eight markets, we allocated the membership according to the distribution of our variable. Therefore, we allocated full membership to 0.02 (the value of the 75th percentile), partial membership to -0.59 (the value of the 50th percentile), and absence of membership to -1.22 (the value of the 25 th percentile).

\section{Internationalization Breadth}

In line with prior research (Kafouros et al., 2012), we operationalized internationalization breadth as the number of markets in which the firm had invested up to year $t$, based on FDIMarkets (for greenfield and brownfield investments), and Zephyr and SDC Platinum data (for mergers and acquisitions investments). We awarded full membership (1) if the firm had invested in at least four foreign markets (namely, the level of our variable at the 75th percentile), partial membership (0.5) if the firm was present in only one foreign market, non-membership (0) if the firm had not invested abroad.

\section{Host Market Institutions}

To measure the quality of host market institutions, we first identified the markets where the firms had operations through their foreign direct investments (FDI), using

\footnotetext{
$\overline{4}$ See WGI at https://info.worldbank.org/governance/wgi/ last accessed on July 20, 2018.
}

FDIMarkets data on greenfield and brownfield FDI, and Zephyr and SDC Platinum data on mergers and acquisitions. Second, we measured the host markets' institutional qualities computing an index estimated from the first principal components of the WGI. Third, we computed the variable Host Market Institutions which for firm $i$ is defined as the average of the quality of the host market institutions where the firm had operations at time $t .{ }^{5}$ To allocate the membership values, we computed the meta-index for all the markets covered by the World Bank Survey. Next, we considered the value of the 75th percentile to define the full membership (i.e., 8.74), the median for partial membership (i.e., 6.55), and the value of the 25th percentile for absence of membership (i.e., 5.30).

\section{Performance}

We measured firm's performance as Return on Assets (ROA) because it is less volatile and less sensitive to heterogeneity in firms' financial structures than other measures, such as Return on Equity, and for this reason is conventionally used for this kind of estimation (e.g., Mishina et al., 2010). To adopt an external criterion for allocating the membership values, we considered the value of ROA at industry level (Fiss, 2011; Misangyi \& Acharya, 2014). ${ }^{6}$ First, we identified the industry to which each firm belongs according to the Thomson Reuters Business Classification (source: Datastream). Next, for each of the industries covered by the firms in our sample, we downloaded the value of the ROA for each year in the analyzed cohort (2003-2012). Therefore, for each firm and the related industry we have annuallybased data on financial outcomes. To calibrate the variable, firms with a performance of $2 \%$ over that of its industry peers are allocated to the set of full membership, those with a performance of $2 \%$ lower than that of their industry peers are allocated to the set of absence of membership, while those with a performance equal to that of the industry peers are allocated to the partial membership set. ${ }^{7}$

\footnotetext{
5 In order to distinguish between domestic firms and firms investing in markets with an institutional quality score equal to 0 , we rescaled the WGI data so that the variable Host Market Institutions assumes value 0 if the firm is a domestic one, that is, if the firm does not face any host market institutional pressure. This is why the magnitude of the variable Host Market Institutions is higher than Home Market Institutions.

${ }^{6}$ See Thomson Reuters Business Classification at https://www.refin itiv.com/ last accessed on July 20, 2018.

7 We noted that the membership-set scores defined using an "external benchmark" are in line with an internal benchmark corresponding to the 75th, 50th, and 25th percentiles of the distribution of the variable computed as the difference between the company's performance at time $t$ and the related industry's performance in the same year.
} 


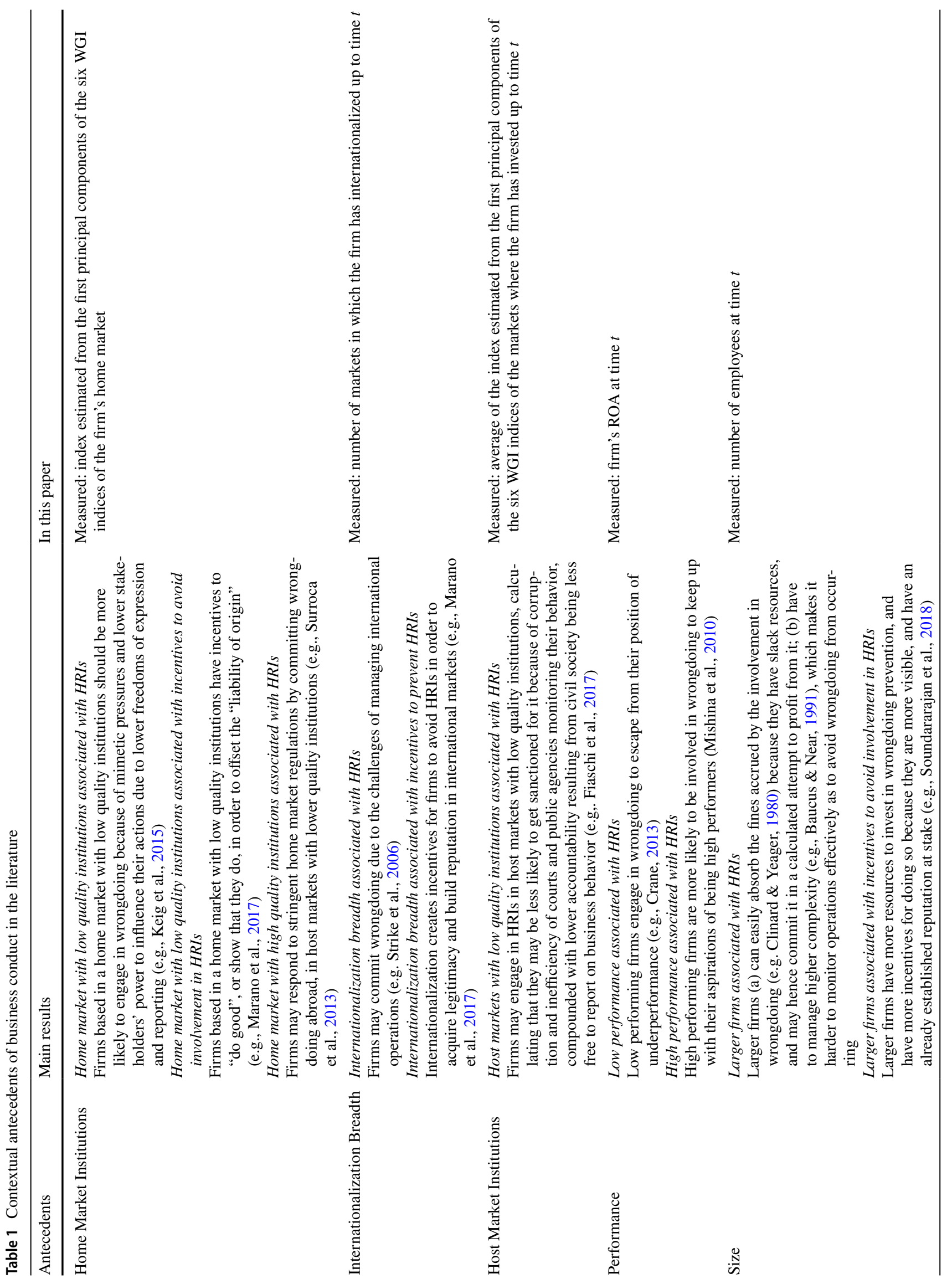




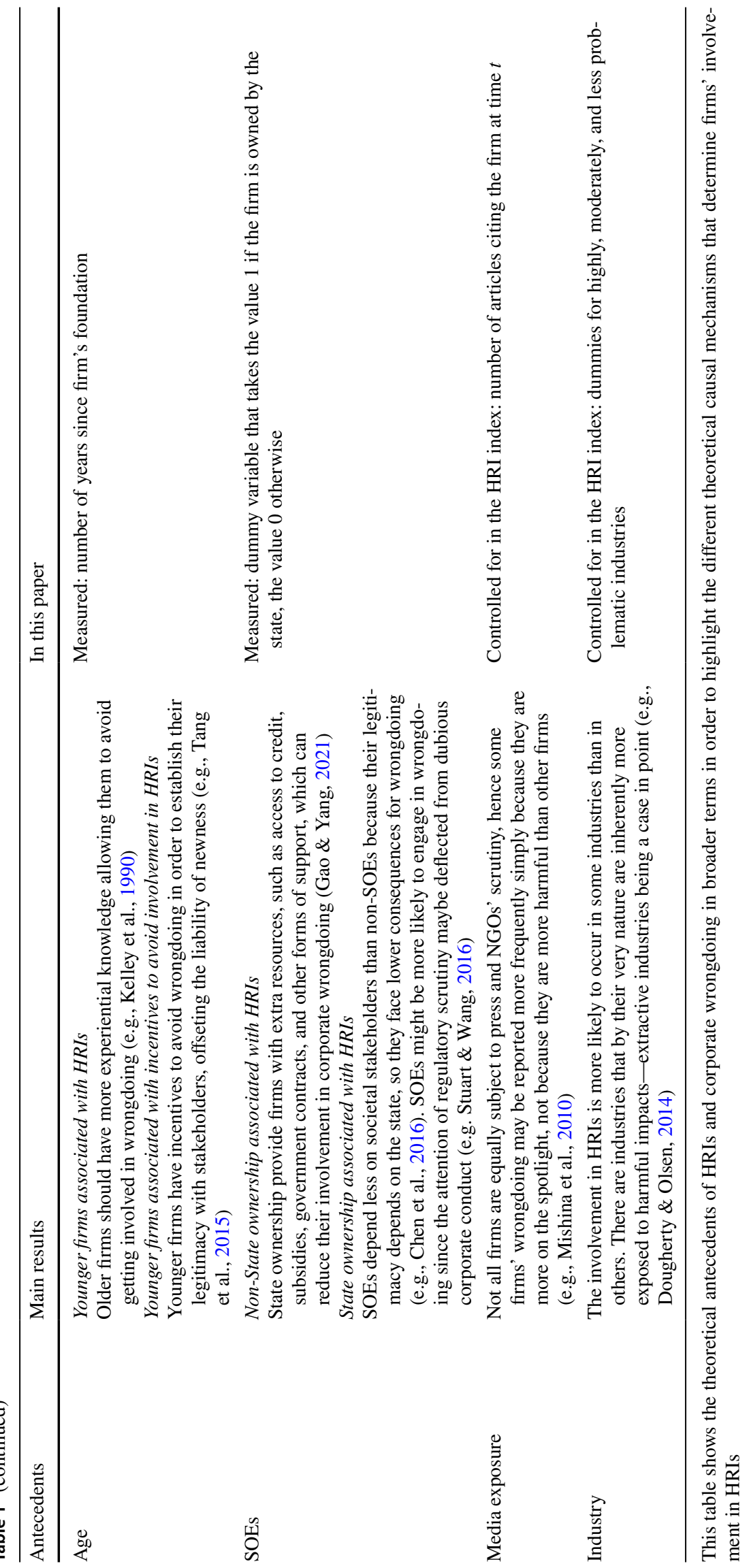




\section{Size}

We proxied firm's size by the logarithm of the number of workers at time $t$. To define allocation to the membership set, we relied on the distribution of the variable firms' size (logarithm of the number of employees) of the firms included in the Forbes 500 Emerging Markets ranking: the value of the 75th percentile (i.e., 10.86) defined full membership (1), the median value (i.e., 9.96) defined partial membership (0.5), and the value of the 25 th percentile (i.e., 8.91) defined nonmembership (0).

\section{Age}

We measured firm age as the number of years since the firm's foundation. A firm of at least 105 years old (which is the 75th percentile's value) is coded as full membership (1), while a 30 -year old firm (i.e., the 50th percentile's value) is coded as partial membership (0.5), and finally a firm of $<$ 5 years old (i.e., the number of years for which a firm is considered as new, according to Verbeke et al., 2019) is coded as non-membership (0).

\section{State Owned Enterprise}

Following established practice (Hou \& Moore, 2010; Stuart \& Wang, 2016), State Owned Enterprise is a dummy variable that takes the value 1 if the firm is state owned, and the value 0 otherwise. We assigned value 1 if the state has full control over the firm or if it is the largest shareholder (Tihanyi et al., 2019). We retrieved the data from Datastream and corporate websites. ${ }^{8}$

\section{Results}

Table 2 shows the descriptive statistics and the correlation matrix of our causal antecedents and the two conditions (i.e., media exposure and industry) we used to condition our outcome variable.

Table 3 reports the results of the fsQCA analysis with the consistency and coverage scores. Consistency measures how well the solution corresponds to the data (Ragin, 2006), and it is separately calculated for each configuration and for the solution as a whole. This measure can range from 0 to 1 , where 1 refers to perfect consistency between theoretical consistency and the data. Solution coverage measures the empirical importance of the solution as a whole (Ragin, 2006). The configurations' coverage is composed of raw and

\footnotetext{
${ }^{8}$ Since State Owned Enterprise is a dummy variable, we do not need a calibration to include it in the QCA.
}

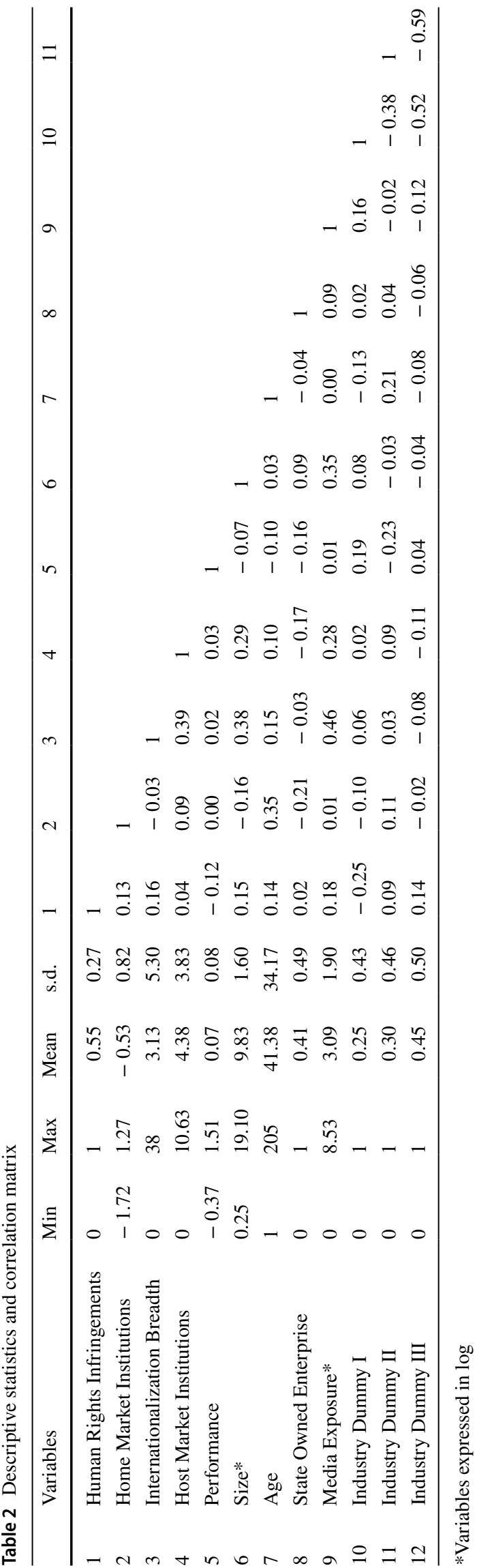


Table 3 Configurations linked to high intensity of Human Rights Infringements

\begin{tabular}{lccc}
\hline Causal conditions & Configuration I & Configuration II & Configuration III \\
\hline Home Market Institutions & $\bullet$ & $\bigotimes$ & \\
Internationalization Breadth & $\bigotimes$ & & \\
Host Market Institutions & & & \\
Performance & & & \\
Size & & & \\
Age & & & \\
State Owned Enterprise & & & \\
\hline Raw coverage & 0 & 0.05 & 0.06 \\
Unique coverage & 0.04 & 0.05 & 0.95 \\
Consistency & & & \\
Solution coverage: 0.13 & & & \\
Solution consistency: 0.95 & & & \\
\hline
\end{tabular}

core causal condition (present); • peripheral causal condition (present); $\bigotimes$ core causal condition (absent); $\otimes$ peripheral causal condition (absent). This format of presenting the result from the fsQCA is based on Fiss (2007). Each column represents a combination of causal conditions (i.e. a configuration), leading to high intensity of HRIs unique coverage in which the former is the extent to which each configuration can explain the outcome, and the latter is a measure of the outcome share explained by a given configuration. When interpreting our results, it is important to take into account that the configurations hereby shown, having a high level of consistency, are very reliably associated with the occurrence of high levels of EFs' involvement in HRIs, and hence have a very strong connection with the occurrence of the outcome. However, as with most fsQCA analyses, the configurations explain only a part (13\%) of the cases where the outcome is present. We chose this approach because it generated a conservative model, anchored in theory and empirically plausible, prioritizing the validity and clarity of the configurations. Our choice is consistent with prior work in fsQCA (e.g., Leischnig \& Woodside, 2019) and with the key tenets of the fsQCA method (Misangyi et al., 2017; Ragin, 2008; Wagemann \& Schneider, 2010).

We find three configurations of antecedents associated with a high intensity of business involvement in HRIs that comply with the fsQCA methodological requirements as expressed by coverage and consistency, theoretical grounding, and empirical plausibility (Misangyi et al., 2017; Ragin, 2008). For transparency reasons, in the parsimonious solutions we report the core conditions as well as the peripheral conditions that feature in intermediate solutions. We do not rely on the core-peripheral distinction in interpreting the results since it is relevant only in the cases where theory indicates that, theoretically, the core conditions should be more important than peripheral conditions. The latter choices agree with prior research findings (Crilly, 2011; Dwivedi et al., 2018). Figure 1 displays the three configurations.

All the configurations represent EFs with a high internationalization breadth. This is consistent with the argument that internationalization increases organizational complexity, making it harder to prevent instances in which one of the geographically disperse operations of the firm harms some societal stakeholder (Strike et al., 2006). Two of the three configurations represent SOEs, which is in line with the argument that state ownership can shield business from the consequences of wrongdoing (Chen et al., 2016); however, our findings show that precisely older and larger SOEs with specific combinations of other antecedents are associated with a high HRI prevalence.

\section{Configuration I}

This is the case of a large, old SOE with operations in markets that have high quality institutions; it has a high 
Fig. 1 Configurations of antecedents leading to high intensity of Human Rights Infringements. Note: The configurations represent the three combinations of antecedents equifinally linked to high intensity of EFs' involvement in HRIs. The signs $(+)$ and $(-)$ denote how each antecedent appears in each configuration that in our sample was linked to the high occurrence of HRIs

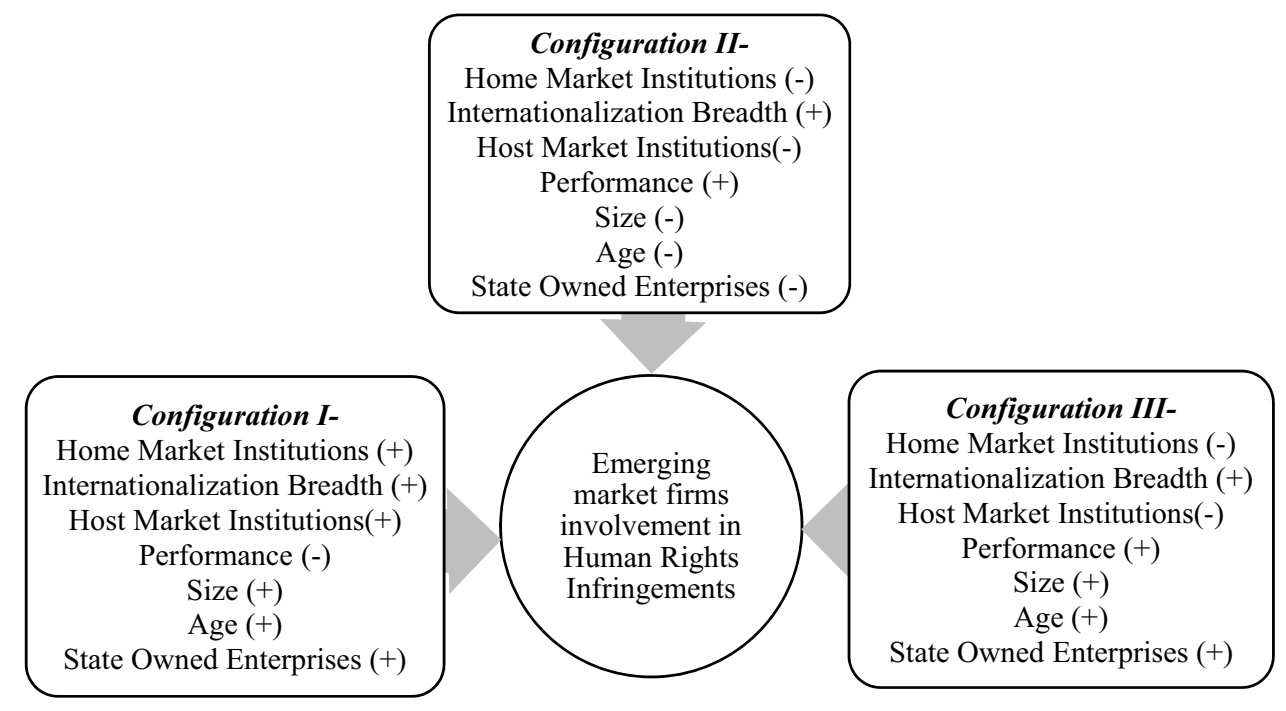

internationalization breadth, and is going through a period of negative economic performance. ${ }^{9}$ An EF internationalizing to high quality host market institutions should face strong institutional pressure to avoid HRIs. This would be first, because HRIs can threaten the firm's attempts to acquire legitimacy and overcome the liability of origin (Fiaschi et al., 2017; Marano et al., 2017; Zyglidopoulos et al., 2016), and second, because adapting mimetically to the institutional context of host markets should make it less likely to be involved in HRIs (Ashforth \& Gibbs, 1990).

This configuration illustrates that the conjunction of other antecedents counteracts these HRI-inhibiting forces. Being an old, large SOE with operations in many countries, this company has comprehensive links to the home country institutions and performs multiple policy functions, ranging from job creation to geopolitical objectives abroad (Musacchio et al., 2015; Vernon, 1979). The home country institutions might be unwilling to sanction the firm if it gets involved in HRIs because an old, large, highly internationalized SOE is also an instrument of foreign policy, and it gets to symbolize the state itself at home and abroad (Shi et al., 2016; Vernon, 1979). This SOE's managers might have been under pressure

\footnotetext{
9 As described in the "Method" section, we are interested in capturing the effects of variation in the quality of home market institutions since emerging markets are not all alike (Marquis \& Raynard, 2015). For this reason, we do not use "absolute" measures, calibrating this antecedent within our sample, so that "high quality home market institutions" means the markets in our sample which have the highest quality institutions (e.g., Brazil, Malaysia, South Africa). In contrast, "low quality home market institutions" means the markets in our sample which have the lowest quality institutions (e.g., China, India, Russia). We calibrated the quality of host market institutions differently because in this case there is greater variation to be captured; that is, the firms observed internationalized to markets comprising the whole range of quality of institutions.
}

to recover from negative performance, possibly because for the home market institutions the financial health of the firm is considered as important, or more important than being involved in HRIs. As Whelan and Muthuri (2017) noted, in emerging markets sanctioning HRIs is less universal in nature than in advanced economies. Also, such HRI inhibition competes with other objectives the state pursues, notably through using SOEs as in fostering industrialization and securing critical resource supplies from abroad (Musacchio et al., 2015).

This firm's managers might therefore have engaged in high HRI behavior because they were trying to recover from negative performance. For example, they could cut corners on measures for preventing HRIs due to awareness that the state would insulate them from the negative implications (Chen et al., 2016; Hou \& Moore, 2010). This configuration shows that state ownership and internationalization breadth, where combined with large size and old age, can alleviate home and host markets' institutional pressures against HRI involvement for firms going through a negative performance period.

Sime Darby, a Malaysian conglomerate owned by the state, founded in the year 1910, illustrates this configuration in our sample. It is a highly internationalized firm with operations in several advanced economies such as the US and Australia; yet its performance is below that of its industry peers. Sime Darby has been involved in multiple HRIs, such as violating the Roundtable on Sustainable Palm Oil principles and appropriating indigenous people's communal land (Sustainalytics, 2014a).

\section{Configuration II}

This is the case of a young, small, highly internationalized firm based in an emerging market with low quality 
institutions, and itself operating in low quality host market institutions. Here, institutional pressure for not committing HRIs is low, both at home and abroad. The low institutional pressure on the firm in this configuration to refrain from HRIs is characterized by a weak rule of law, corruption, an inefficient judiciary, and the fact that some home stakeholders, such as NGOs, might not be free to oppose the HRIs openly (Keig et al., 2015). The firm is internationalized in host markets with low quality institutions, that face similar conditions to those experienced in the home market, such as corruption and uncertain regulations. The company might even benefit from these poor conditions (Cuervo-Cazurra et al., 2018), for example by being able to bribe its way out of an HRI difficulty.

The interplay between home and host market institutions, however, provides only a partial explanation for HRIs. In line with strain theory, the firm, even if performing positively, could be struggling to prevent HRIs because it is young, small, and operating in a large number of markets without state support. It is possible that the firm's managers, whose careers are linked to the financial returns they generate (Bruton et al., 2015), prioritize economic performance at all costs. For example, they could under-invest in HRI prevention, whilst stretching organizational resources to support growth and international expansion at an early stage (i.e., while the firm is still young and small), taking advantage of the fact that both at home and abroad institutional pressure to avoid HRIs is low.

The Zijin Mining Company, a small and young, non-stateowned Chinese company, which operates mines and other extractive activities in several host markets with low quality institutions, illustrates this configuration in our sample. In the period we examined, Zijin Mining was performing very well, achieving higher returns than the industry average; yet, it was involved in several infringements of workers' and communities' human rights in multiple host markets, such as Myanmar and Peru (Sustainalytics, 2014b).

\section{Configuration III}

This is the case of an old, large, high performing SOE based in a home market with low quality institutions, with high internationalization breadth, and itself operating in low quality host market institutions. Similar to Configuration II, this is a case where both home and host markets are characterized by weak institutions, which is in line with standard institutional theory predictions. In this case, the firm is old, large, high performing, and state owned, thus it operates in conditions that could insulate it from institutional pressures. Thus, Configuration III is consistent with exploitative business conduct in which the firm takes advantage of both the low regulated institutional context where it operates, and the protection against HRI consequences afforded an old, large, highly internationalized SOE. This configuration, inconsistent with strain theory, illustrates that firms with no constraints also get involved in HRIs when they operate in low home and host market institutions, and additionally, benefit from the insulating effects linked to being an old, large, and highly internationalized SOE.

Larsen \& Toubro Ltd., a large state-owned Indian company founded in 1938, that provides construction services, illustrates this configuration in our sample. This firm operates in Bangladesh, Brazil, China, Indonesia, Malaysia, Oman, Saudi Arabia, and South Africa. In the period we examine, Larsen \& Toubro Ltd. was performing very well, achieved higher returns than the industry average, and yet, it was involved in several HRIs. For example, it faced allegations of discriminatory practices against female workers in Bhutan (Sustainalytics, 2014c).

\section{Discussion}

Our research answers to calls for further investigating the antecedents of business involvement in HRIs (Nieri \& Giuliani, 2018; Wettstein et al., 2019). These infringements are a systemic social problem (Churchman, 1967) which emerges out of a complex combination of conditions that exist both internally (firm-level antecedents) and externally (home and host market institutions) to the firm. Using fsQCA allows us to examine HRI antecedents in a contextual manner, capturing the complex causality at play, whereby interactions between various antecedents create unique contexts of business involvement in HRIs, even if none of the antecedents, per se, would be sufficient for HRIs to occur. We contribute to the debate with a configurational perspective on the situational antecedents of HRIs, examining the complex causality at play and the interactions between institutional and firm-level antecedents.

Our results illustrate that institutional pressures are an important determinant of firm behavior. In two cases (Configurations II and III), the firm has a high internationalization breadth and is operating in low quality home and host market institutions, where the consequences of HRIs might not be sufficiently severe, regardless of whether the firm is old, large, and state owned (Configuration III) or young, small, and not state owned (Configuration II).

We add a nuance to strain theory's base argument that resource constraints lead to HRIs, as two configurations (Configurations I and III) we found represent large, old firms that should have had sufficient resources to prevent HRIs. The large, old, high performing SOEs of Configuration III in particular, are not under strain, which demonstrates that non-strained firms also commit HRIs if institutional pressure to avoid reprehensible conduct is low. Additionally, only one of these configurations depicts an underperforming firm 
(Configuration I). Configuration II is consistent with strain theory in representing a firm that, although it is performing well, fails to prevent HRIs while managing a highly internationalized organizational structure because as a small and young firm it lacks experience and resources, and because it is exposed to low institutional pressure to refrain from HRIs. Older, larger EFs that are not state owned might invest more resources in HRI prevention, possibly to avoid reputational damage at home (Gao et al., 2017), or to offset the liability of origin because they are expanding internationally (Marano et al., 2017). It is possible that, as Mishina et al. (2010) suggest, managers of the firms in Configuration II were acting overconfidently and in a risk-taking manner precisely because the firm was performing well, and that this led to HRIs. We do not have sufficient information to develop this argument, but we suggest it as an avenue for further research. It would be interesting to build further evidence to understand whether firms commit HRIs as a pro-active means to an end, or whether, as the qualitative evidence assembled by Whiteman and Cooper (2016) suggests, the infringements occur as a result of underinvestment in preventive measures and overall disregard for the topic.

We also provide interesting insight into the effects of internationalization breadth. Our study shows that although some argue that internationalization provides incentives for EFs to refrain from HRIs in order to gain global legitimacy (Fiaschi et al., 2015; Marano et al., 2017; Zyglidopoulos et al., 2016), in conjunction with other antecedents, it can also be a driver of HRIs: all our configurations represent firms that have internationalized to a large number of markets.

Our study supports the arguments that SOEs' legitimacy stems from the state, their central stakeholder, which makes them less dependent on other societal stakeholders, such as the parties injured by their HRIs. Often the older, larger SOEs are most deeply embedded in home institutions, and hence most likely to receive state support (Tihanyi et al., 2019). Old, large, highly internationalized SOEs are a visible embodiment of the state and of home institutions. Their size, age, and links to the state establish legitimacy with home stakeholders, all of which can insulate them from institutional pressure to avoid HRIs. As Hou and Moore (2010, p. 332) state in their study of state ownership's effects on fraud in China, "although the corporate governance in SOEs with large state ownership tends to be worse, their strong political connection could help to secure favorable regulatory conditions and extricate them from fraud inspections." Old, large, more established SOEs perhaps engage in HRIs because they have developed organizational knowledge that helps them minimize the consequences of the HRIs. This would include effective ways to leverage ties with the state, complex networks tying their top management to state agencies, and the ability to navigate legal cases brought against them. We show that, although large, old, internationalized SOEs might be a key type of organization to keep under surveillance regarding human rights, for EFs state ownership is neither necessary nor sufficient to be highly involved in HRIs. Configuration II represents high HRI involvement of a young, small firm that is not state owned, with geographically diversified operations, operating in low quality market institutions, and performing well.

\section{Conclusion}

Business conduct that infringes on human rights is a menace to numerous constituencies; not only do workers whose rights are violated by lack of safety standards at work pay a price, but also wider communities such as those residing in the vicinity of contaminating plants or indigenous groups deprived of their rights to land by mining companies whose projects were initiated without duly consulting the affected people. Most empirical studies investigating business and human rights are qualitative. They focus on a specific industry, firm, or type of human rights violation. We do not deny the importance of single case studies; nevertheless, the scarcity of large-scale empirical analyses on the causes of human rights impacts remain concerning (Olsen et al., 2020). Our study takes a modest first step toward addressing such a gap, using a multi-year database that we assembled to document all types of corporate HRIs included in the 1948 Universal Declaration of Human Rights, perpetrated by firms operating in different industries and locations.

A further empirical gap in the debate on business and human rights refers to how it has thus far focused on advanced market firms, although EFs have gradually been acquiring importance as investors, exporters, employers, and innovators in the world economy. We propose that to advance our understanding of corporate involvement in HRIs we need to move away from the Global North bias that affects much management research (Palmer et al., 2016). As Whelan and Muthuri (2017) argued, regarding business and human rights in emerging markets, national institutions can take approaches different to those prevailing in the Global North, which influence the conduct of business, particularly in state owned businesses. Our study contributes to the debate by building empirical evidence of involvement in HRIs by 245 firms based in eight emerging markets, observed from 2003 to 2012.

The literature on HRI antecedents is characterized by conflicting arguments and a lack of consensus on causal mechanisms, partly due to the rather incipient nature of empirical work on this subject. We contend that, besides the scarcity of empirical evidence, lack of consensus on the effects of different antecedents stems from the fact that they tend to be examined with a linear causality logic. The 
complex interactions between antecedents, which create the circumstances in which firms engage in HRIs, remain understudied. Also under-investigated, is the possibility that there can be multiple combinations of antecedents (or configurations) that equifinally lead to HRIs. Using a configurational logic, we address these research gaps, finding three equifinal configurations of EFs involvement in human rights infringements.

Our findings should be considered with some caution. First, empirically, we have captured a sample of firms from eight emerging markets. We believe extending the research to a larger number of home markets and firms would be useful to verify whether different behaviors can be disclosed. We examined the largest public firms in these eight markets, which limits the extent to which we can theorize about smaller firms, especially the sort of small domestic businesses that dominate in emerging markets. Second, as with other studies on corporate wrongdoing, we rely on externally reported abuses, which could underrepresent the extent of HRIs, especially those perpetrated by small, less visible firms, and in markets where the rule of law is weak. In our study's context, we account for this bias by controlling for the differing intensity of reporting activity of the media, NGOs, and other watchdog organizations disclosing the firms' operations, as this is one of the ways in which the news about HRIs get broadcasted. Third, state-ownership as measured in this paper provides little information on the magnitude and quality of state investment and the corporate strategies behind such an ownership structure. Unfortunately, data on the percentages the state owns and how they changed in the cohort we analyzed, is not available for all the companies in our sample. We would therefore recommend that future research use more refined measures of what constitutes an SOE. Fourth, our measure of internationalization breadth relies only on foreign direct investment deals, and counts the number of different countries into which the firm has expanded up to a given year. Further research might explore different dimensions of internationalization strategies which could affect firms' involvement in HRIs.

Interesting avenues for further research include, among others, studying the nature of the economies in which the firms are based in more detail, for example by including sets of markets with different varieties of capitalist systems in place, or a more fine-grained analysis of the specific types of HRIs, investigating the managerial decisions that lead to HRIs and the managerial team involved. Another such avenue could be a longitudinal study of the causal link between HRIs and subsequent performance metrics.

The configurational research design we adopted bridges the institutional and strain theory streams of the literature explaining corporate wrongdoing, and by doing so, it illustrates the value of examining how antecedents grounded in different theoretical traditions interact with each other. We show that institutions provide important incentives regulating firm conduct, but that such incentives operate differently for firms, depending on their age, size, performance, internationalization and whether they are state owned or not. In a similar vein, we argue that firm-level antecedents of HRIs anchored in strain theory should also be seen as contingent to the institutional context in which business conduct is situated. Our configurational perspective provides a nuanced view of the complex situations in which HRIs and other forms of corporate wrongdoing occur, advancing research on the subject. We believe that this study is a small step towards more realistic and granular explanations of the causes of business involvement in HRIs, and that such explanations could help practitioners develop better instruments for regulating, sanctioning, and hopefully limiting business conduct that breaches human rights.

\section{Appendix}

\section{M-quantile regression}

To deal with the caveats of measuring corporate involvement in HRIs (i.e. media exposure, industry, and time) highlighted by prior research, we relied on the methodology developed by Fiaschi et al. (2020). Specifically, to measure firms' involvement in corporate wrongdoing, they suggested the use of the M-quantile regression which provides a 'quantile-like' generalization of the mean regression (Breckling \& Chambers, 1988). Given that our measurement is based on the number of HRIs encountered in each firm every year, similarly to Fiaschi et al., we followed Tzavidis et al. (2015) who propose using the logarithm as link function when the dependent variable follows a Poisson distribution (that is, the dependent variable is a count). The authors suggest the log-linear specification for count data:

$M Q_{y}\left(\tau \mid \mathbf{x}_{j t} ; \psi\right)=k_{j t} \exp \left(\mathbf{x}_{j t}^{T} \boldsymbol{\beta}_{\tau}\right)$,

where $k_{j t}$ is an offset term, $\mathbf{x}_{j t}$ is the vector of covariates for firm $j$ at time $t, \boldsymbol{\beta}_{\tau}$ is the vector of regression coefficients and $\psi$ is the appropriate influence function. Based on Tzavidis et al. (2016) and Cantoni and Ronchetti (2001), the M-quantile coefficient $\tau_{j t}$ is defined such that $y_{j t}=M Q_{y}\left(\tau \mid \mathbf{x}_{j t} ; \psi\right)$ and it takes values between 0 and $1 ; \tau_{j t}$ indicates the quantile of the distribution of $y_{j t}$ each firm is estimated to belong to in each year, conditioned to the firm-level variables included in the M-quantile regression, which in our case, based on our earlier considerations, include: (i) firms' media exposure, (ii) firms' industry, and (iii) time. In the limiting case where only the intercept is included in the regression, $\tau_{j t}$ indicates the quantile of the observed distribution of HRIs a 
Table 4 Results of M-quantile regression

\begin{tabular}{|c|c|c|c|c|c|c|c|c|c|c|}
\hline & \multicolumn{2}{|l|}{$\tau=0.10$} & \multicolumn{2}{|l|}{$\tau=0.25$} & \multicolumn{2}{|l|}{$\tau=0.50$} & \multicolumn{2}{|l|}{$\tau=0.75$} & \multicolumn{2}{|l|}{$\tau=0.90$} \\
\hline & Estimate & $p$-value & Estimate & $p$-value & Estimate & $p$-value & Estimate & $p$-value & Estimate & $p$-value \\
\hline Intercept & -5.14 & 0.00 & -3.66 & 0.00 & -2.15 & 0.00 & -0.98 & 0.00 & -0.27 & 0.01 \\
\hline Media Exposure & 0.60 & 0.00 & 0.53 & 0.00 & 0.43 & 0.00 & 0.35 & 0.00 & 0.29 & 0.00 \\
\hline Industry Dummy II & -0.68 & 0.00 & -0.57 & 0.00 & -0.58 & 0.00 & -0.59 & 0.00 & -0.57 & 0.00 \\
\hline Industry Dummy III & -1.01 & 0.00 & -0.81 & 0.00 & -0.62 & 0.00 & -0.56 & 0.00 & -0.54 & 0.00 \\
\hline Time Dummies & Included & & Included & & Included & & Included & & Included & \\
\hline Pseudo- $R^{2}$ & 0.19 & & 0.24 & & 0.25 & & 0.32 & & 0.33 & \\
\hline
\end{tabular}

firm belongs to; for example, a value of $\tau_{j t}=0.90$ for a firm indicates that the firm belongs to the top $10 \%$ of the reported controversies' distribution.

We computed a $\tau_{j t}$ for each firm and in each year included in our sample. This means that, through the M-quantile regression we computed an HRIs index (Human Rights Infringements) which ranges from 0 to 1 , with 0 and 1 respectively indicating lower and upper boundaries of the firms' involvement in HRIs.

Table 4 shows the results of the M-quantile regressions. We found that the conditional variables (Media Exposure, Industry Dummy II, Industry Dummy III, and Time Dummies) are statististically significant at $1 \%$ significance level. The significance of the coefficient of Media Exposure, and Industry and Time Dummies highlights the importance of conditioning the number of HRIs in which each firm has been involved in each year to those conditional variables. Indeed, all these variables being significant means that our measure of Human Rights Infringements would be biased if we not take those variables into consideration. Table 4 also shows the pseudo- $R^{2}$ at different $\tau$, which is a local relative measure of goodness-of-fit of the M-quantile regression model with respect to the null model at a specific $\tau$ (Bianchi et al., 2018).

Acknowledgements We are grateful to our editor, Stelios Zyglidopoulos, and two anonymous reviewers for their invaluable guidance and support throughout the review process. Thanks go also to Elisa Giuliani and Ruth Aguilera for their invaluable feedback for this study. The idea for this paper was presented at a workshop on research method organized at the International Development Department of King's College in January 2019—we thank Prof. Peter Kingstone, Gabriela Gutierrez Huerter, and Felipe Diaz Rangel for their insightful comments. We feel indebted to Nicola Salvati for his insights on M-quantile regression. All disclaimers apply.

Funding Open access funding provided by Università di Pisa within the CRUI-CARE Agreement.

Open Access This article is licensed under a Creative Commons Attribution 4.0 International License, which permits use, sharing, adaptation, distribution and reproduction in any medium or format, as long as you give appropriate credit to the original author(s) and the source, provide a link to the Creative Commons licence, and indicate if changes were made. The images or other third party material in this article are included in the article's Creative Commons licence, unless indicated otherwise in a credit line to the material. If material is not included in the article's Creative Commons licence and your intended use is not permitted by statutory regulation or exceeds the permitted use, you will need to obtain permission directly from the copyright holder. To view a copy of this licence, visit http://creativecommons.org/licenses/by/4.0/.

\section{References}

Armstrong, J. S. (1977). Social irresponsibility in management. Journal of Business Research, 5(3), 185-213.

Ashforth, B. E., \& Gibbs, B. W. (1990). The double-edge of organizational legitimation. Organization Science, 1(2), 177-194.

Avery, C. (2009). Why all companies should address human rights. Business \& Human Rights Resource Centre.

Baucus, M. S., \& Near, J. P. (1991). Can illegal corporate behavior be predicted? An event history analysis. Academy of Management Journal, 34(1), 9-36.

Baumann-Pauly, D., Nolan, J., van Heerden, A., \& Samway, M. (2017). Industry-specific multi-stakeholder initiatives that govern corporate human rights standards: Legitimacy assessments of the fair labor association and the Global Network Initiative. Journal of Business Ethics, 143(4), 771-787.

Bernaz, N. (2016). Business and human rights. History, law and policy-Bridging the accountability gap. Routledge.

Bianchi, A., Fabrizi, E., Salvati, N., \& Tzavidis, N. (2018). Estimation and testing in M-quantile regression with applications to small area estimation. International Statistical Review, 86(3), 541-570.

Breckling, J., \& Chambers, R. (1988). M-quantiles. Biometrika Trust, 75(4), 761-771.

Brenes, E. R., Ciravegna, L., \& Pichardo, C. A. (2019). Managing institutional voids: A configurational approach to understanding high performance antecedents. Journal of Business Research, 105, 345-358.

Bromiley, P. (2010). Looking at prospect theory. Strategic Management Journal, 31, 1357-1370.

Bruderl, J., \& Schussler, R. (1990). Organizational mortality: The liabilities of newness and adolescence. Administrative Science Quarterly, 35(4), 530-547.

Bruton, G. D., Peng, M. W., Xu, K., Stan, C., \& Ahlstrom, D. (2015). State-owned enterprises around the world as hybrid organizations. Academy of Management Perspectives, 29(1), 92-114.

Buhmann, K. (2017). Changing sustainability norms through communication processes: The emergence of The business and human rights regime as transnational law. Edward Elgar Publishing. 
Calvano, L. (2008). Multinational corporations and local communities: A critical analysis of conflict. Journal of Business Ethics, 82(4), 793-805. https://doi.org/10.1007/s10551-007-9593-z

Campbell, J. L. (2007). Why would corporations behave in socially responsible ways? An institutional theory of corporate social responsibility. Academy of Management Review, 32(3), 946-967.

Cantoni, E., \& Ronchetti, E. (2001). Robust inference for generalized linear models. Journal of the American Statistical Association, 96(455), 1022-1030.

Chen, J., Cumming, D., Hou, W., \& Lee, E. (2016). CEO accountability for corporate fraud: Evidence from the split share structure reform in China. Journal of Business Ethics, 138, 787-806.

Cheung, Y., Jiang, P., Lu, T., \& Limpaphayom, P. (2010). Corporate governance in China: A step forward. European Financial Management, 16(1), 94-123.

Churchman, C. W. (1967). Guest editorial: Wicked problems. Management Science, 14(4), 141-142.

Clinard, M., \& Yeager, P. (1980). Corporate crime: The first comprehensive account of illegal practices among America's top corporations. Free Press.

Crane, A. (2013). Modern slavery as a management practice: Exploring the conditions and capabilities for human exploitation. Academy of Management Review, 38(1), 49-69.

Crilly, D. (2011). Predicting stakeholder orientation in the multinational enterprise: A mid-range theory. Journal of International Business Studies, 42(5), 694-717.

Cuervo-Cazurra, A., Ciravegna, L., Melgarejo, M., \& Lopez, L. (2018). Home country uncertainty and the internationalization-performance relationship: Building an uncertainty management capability. Journal of World Business, 53(2), 209-221.

DiMaggio, P. J., \& Powell, W. W. (1983). The iron cage revisited: Institutional isomorphism and collective rationality in organizational fields. American Sociological Review, 48(2), 147-160.

Dougherty, M. L., \& Olsen, T. D. (2014). Taking terrain literally: Grounding local adaptation to corporate social responsibility in the extractive industries. Journal of Business Ethics, 119(3), 423-434.

Du, S., \& Vieira, E. T. (2012). Striving for legitimacy through corporate social responsibility: Insights from oil companies. Journal of Business Ethics, 110(4), 413-427.

Dwivedi, P., Joshi, A., \& Misangyi, V. F. (2018). Gender-inclusive gatekeeping: How (mostly male) predecessors influence the success of female CEOs. Academy of Management Journal, 61(2), 379-404.

Epstein, J., Duerr, D., Kenworthy, L., \& Ragin, C. (2008). Comparative employment performance: A fuzzy-set analysis. In Kenworthy L., Hicks, A. (Eds.), Method and substance in macrocomparative analysis. Research methods series (pp. 67-90). Palgrave Macmillan.

Fasterling, B., \& Demuijnck, G. (2013). Human rights in the void? Due diligence in the UN Guiding Principles on Business and Human Rights. Journal of Business Ethics, 116(4), 799-814.

Ferraro, F., Etzion, D., \& Gehman, J. (2015). Tackling grand challenges pragmatically: Robust action revisited. Organization Studies, 36(3), 363-390.

Fiaschi, D., Giuliani, E., \& Nieri, F. (2015). BRIC companies seeking legitimacy through corporate social responsibility. UNCTAD Transnational Corporations, 22(3), 5-42.

Fiaschi, D., Giuliani, E., \& Nieri, F. (2017). Overcoming the liability of origin by doing no-harm: Emerging country firms' social irresponsibility as they go global. Journal of World Business, 52(4), 546-563.

Fiaschi, D., Giuliani, E., Nieri, F., \& Salvati, N. (2020). How bad is your company? Measuring corporate wrongdoing beyond the magic of ESG metrics. Business Horizons, 63(3), 287-299.
Fiss, P. C. (2007). A set-theoretic approach to organizational configurations. Academy of Management Review, 32(4), 1180-1198.

Fiss, P. C. (2011). Building better causal theories: A fuzzy set approach to typologies in organization research. Academy of Management Journal, 54(2), 393-420.

Gao, Y., \& Yang, H. (2021). Does ownership matter? Firm ownership and corporate illegality in China. Journal of Business Ethics, $168,431-445$.

Gao, C., Zuzul, T., Jones, G., \& Khanna, T. (2017). Overcoming institutional voids: A reputation-based view of long-run survival. Strategic Management Journal, 38(11), 2147-2167.

González-Cantón, C., Boulos, S., \& Sánchez-Garrido, P. (2019). Exploring the link between human rights, the capability approach and corporate responsibility. Journal of Business Ethics, 160(4), 865-879.

Greve, H. R., Palmer, D., \& Pozner, J. (2010). Organizations gone wild: The causes, processes, and consequences of organizational misconduct. Academy of Management Annals, 4(1), 53-107.

Gul, F. A., Kim, J., \& Qiu, A. A. (2010). Ownership concentration, foreign shareholding, audit quality, and stock price synchronicity: Evidence from China. Journal of Financial Economics, 95(3), 425-442.

Hamann, R., Makaula, L., Ziervogel, G., Shearing, C., \& Zhang, A. (2020). Strategic responses to grand challenges: Why and how corporations build community resilience. Journal of Business Ethics, 161(4), 835-853.

Hillman, A. J. (2005). Politicians on the board of directors: Do connections affect the bottom line? Journal of Management, 31(3), 464-481.

Hou, W., \& Moore, G. (2010). Player and referee roles held jointly: The effect of state ownership on China's regulatory enforcement against fraud. Journal of Business Ethics, 95, 317-335.

Jackson, G., \& Deeg, R. (2008). Comparing capitalisms: Understanding institutional diversity and its implications for international business. Journal of International Business Studies, 39(4), 540-561.

Jackson, G., Bartosch, J., Avetisyan, E., Kinderman, D., \& Knudsen, J. S. (2020). Mandatory non-financial disclosure and its influence on CSR: An international comparison. Journal of Business Ethics, 162(2), 323-342.

Judge, W. Q., Fainshmidt, S., \& Brown, J. L. (2014). Which model of capitalism best delivers both wealth and equality? Journal of International Business Studies, 45(4), 363-386.

Kafouros, M. I., Buckley, P. J., \& Clegg, J. (2012). The effects of global knowledge reservoirs on the productivity of multinational enterprises: The role of international depth and breadth. Research Policy, 41(5), 848-861. https://doi.org/10.1016/j.respol.2012. 02.007

Kaufmann, D., Kraay, A., \& Mastruzzi, M. (2011). The worldwide governance indicators: Methodology and analytical issues. World Bank Policy Research Working Paper No. 5430. https://doi.org/ 10.1017/S1876404511200046

Keig, D. L., Brouthers, L. E., \& Marshall, V. B. (2015). Formal and informal corruption environments and multinational enterprise social irresponsibility. Journal of Management Studies, 52(1), 89-116.

Kelley, S. W., Ferrell, O. C., \& Skinner, S. J. (1990). Ethical behavior among marketing researchers: An assessment of selected demographic characteristics. Journal of Business Ethics, 9(8), 681-688.

Khanna, T., \& Palepu, K. (1997). Why focused strategies may be wrong for emerging markets. Harvard Business Review, 75(4), 41-51.

Kolk, A., \& Van Tulder, R. (2004). Ethics in international business: Multinational approaches to child labor. Journal of World Business, 39(1), 49-60. 
Kostova, T., \& Roth, K. (2002). Adoption of an organizational practice by subsidiaries of multinational corporations: Institutional and relational effects. Academy of Management Journal, 45(1), 215-233.

Kowalski, P., Buge, M., Sztajerowska, M., \& Egeland, M. (2013). State-owned enterprises: Trade effects and policy implications. OECD Trade Policy Paper (Vol. 147).

Leischnig, A., \& Woodside, A. G. (2019). Who approves fraudulence? Configurational causes of consumers' unethical judgments. Journal of Business Ethics, 158(3), 713-726.

Lewellyn, K. B., \& Muller-Kahle, M. I. (2020). The corporate board glass ceiling: The role of empowerment and culture in shaping board gender diversity. Journal of Business Ethics, 165(2), 329-346.

Li, W., \& Zhang, R. (2010). Corporate social responsibility, ownership structure, and political interference: Evidence from China. Journal of Business Ethics, 96(4), 631-645. https://doi.org/10. 1007/s10551-010-0488-z

Maher, R. (2020). De-contextualized corporate human rights benchmarks: Whose perspective counts? See disclaimer. Business and Human Rights Journal, 5(1), 156-163.

Maher, R., Neumann, M., \& Slot Lykke, M. (2021). Extracting legitimacy: An analysis of corporate responses to accusations of human rights abuses. Journal of Business Ethics. https://doi. org/10.1007/s10551-020-04678-Z

Marano, V., Tashman, P., \& Kostova, T. (2017). Escaping the iron cage: Liabilities of origin and CSR reporting of emerging market multinational enterprises. Journal of International Business Studies, 48(3), 386-408.

Marquis, C., \& Raynard, M. (2015). Institutional strategies in emerging markets. Academy of Management Annals, 9(1), 291-335.

Martin, K. D., Cullen, J. B., \& Johnson, J. L. (2007). Deciding to bribe: A cross-level analysis of firm and home country influences on bribery activity. Academy of Management Journal, 50(6), 1401-1422.

Mena, S., de Leede, M., Baumann, D., Black, N., Lindeman, S., \& McShane, L. (2010). Advancing the business and human rights agenda: Dialogue, empowerment, and constructive engagement. Journal of Business Ethics, 93(1), 161-188.

Merton, R. K. (1938). Social structure and anomie. American Sociological Review, 3(5), 672-682.

Meyer, K. E., \& Peng, M. W. (2016). Theoretical foundations of emerging economy business research. Journal of International Business Studies, 47, 3-22.

Misangyi, V. F., \& Acharya, A. G. (2014). Substitutes or complements? A configurational examination of corporate governance mechanisms. Academy of Management Journal, 57(6), $1681-1705$

Misangyi, V. F., Greckhamer, T., Furnari, S., Fiss, P. C., Crilly, D., \& Aguilera, R. (2017). Embracing causal complexity: The emergence of a neo-configurational perspective. Journal of Management, 43(1), 255-282.

Mishina, Y., Dykes, B. J., Block, E. S., \& Pollock, T. G. (2010). Why "good" firms do bad things: The effects of high aspirations, high expectations, and prominence on the incidence of corporate illegality. Academy of Management Journal, 53(4), 701-722.

Mudambi, R., \& Zahra, S. A. (2007). The survival of international new ventures. Journal of International Business Studies, 38(2), 333-352.

Musacchio, A., Lazzarini, S. G., \& Aguilera, R. V. (2015). New varieties of state capitalism: Strategic and governance implications. Academy of Management Perspectives, 29(1), 115-131.

Nieri, F., \& Giuliani, E. (2018). International business and corporate wrongdoing: A review and research agenda. In D. Castellani, R. Narula, N. Quyen, I. Surdu, \& W. Ames (Eds.), Contemporary issues in international business (pp. 35-53). Palgrave Macmillan.
Olsen, T. D., Parsells-Johnson, B., Bernal Bermúdez, L., Westermann Behaylo, M., \& Payne, L. A. (2020). Bridging the data gap: Exploring pillar III and victims' access to remedy. https://www. ohchr.org/Documents/Issues/Business/ARP/Olsen_Bridging_ Data_Gap_January2020.pdf

Palmer, D. (2012). Normal organizational wrongdoing. Oxford University Press.

Palmer, D., Greenwood, R., \& Smith-Crowe, K. (2016). The imbalances and limitations of theory and research on organizational wrongdoing. In D. Palmer, R. Greenwood, \& K. Smith-Crowe (Eds.), Organizational wrongdoing: Key perspectives and new directions (pp. 1-16). Cambridge University Press.

Prado, A. M., \& Woodside, A. G. (2015). Deepening understanding of certification adoption and non-adoption of international-supplier ethical standards. Journal of Business Ethics, 132(1), 105-125.

Ragin, C. C. (2000). Fuzzy-set social science. University of Chicago Press.

Ragin, C. C. (2006). Set relations in social research: Evaluating their consistency and coverage. Political Analysis, 14(3), 291-310.

Ragin, C. C. (2008). Redesigning social inquiry: Fuzzy sets and beyond. University of Chicago Press.

Rihoux, B., \& Ragin, C. C. (2008). Configurational comparative methods: Qualitative comparative analysis (QCA) and related techniques (Vol. 51). Sage Publications.

Ruggie, J. G. (2008). Report of the Special Representative of the Secretary-General on the issue of human rights and transnational corporations and other business enterprises. A/HRC/8/5. http://www.mitpressjournals.org. https://doi.org/10.1162/itgg. 2008.3.2.189

Salomon, R., \& Wu, Z. (2012). Institutional distance and local isomorphism strategy. Journal of International Business Studies, 43(4), 343-367. https://doi.org/10.1057/jibs.2012.3

Schneider, C. Q., \& Wagemann, C. (2006). Reducing complexity in qualitative comparative analysis (QCA): Remote and proximate factors and the consolidation of democracy. European Journal of Political Research, 45(5), 751-786.

Schneider, C. Q., \& Wagemann, C. (2012). Set-theoretic methods for the social sciences: A guide to qualitative comparative analysis. Cambridge University Press.

Schrempf-Stirling, J., \& Wettstein, F. (2017). Beyond guilty verdicts: Human rights litigation and its impact on corporations' human rights policies. Journal of Business Ethics, 145(3), 545-562.

Shi, W., Hoskisson, R. E., \& Zhang, Y. A. (2016). A geopolitical perspective into the opposition to globalizing state-owned enterprises in target states. Global Strategy Journal, 6(1), 13-30.

Sjåfjell, B. (2020). How company law has failed human rights-And what to do about it. Business and Human Rights Journal, 5(2), 179-199.

Soundararajan, V., Spence, L. J., \& Rees, C. (2018). Small business and social irresponsibility in developing countries: Working conditions and "evasion" institutional work. Business \& Society, 57(7), 1301-1336.

Spencer, J., \& Gomez, C. (2011). MNEs and corruption: The impact of national institutions and subsidiary strategy. Strategic Management Journal, 32, 280-300.

Staw, B. M., \& Szwajkowski, E. (1975). Scarcity-munificence component of organizational environments and the commission of illegal acts. Administrative Science Quarterly, 20(3), 345-354.

Strike, V. M., Gao, J., \& Bansal, P. (2006). Being good while being bad: Social responsibility and the international diversification of US firms. Journal of International Business Studies, 37(6), $850-862$.

Stuart, T., \& Wang, Y. (2016). Who cooks the books in China, and does it pay? Evidence from private, high-technology firms. Strategic Management Journal, 37(13), 2658-2676. 
Surroca, J., Tribo, J. A., \& Zahra, S. A. (2013). Stakeholder pressure on MNEs and the transfer of socially irresponsible practices to subsidiaries. Academy of Management Journal, 56(2), 549-572.

Sustainalytics. (2014a). Sime Darby Berhad controversy report. Sustainalytics. (2014b). Zijin Mining Group Co. controversy report. Sustainalytics. (2014c). Larsen \& Toubro Ltd. controversy report.

Tang, Y., Qian, C., Chen, G., \& Rui, S. (2015). How CEO hubris affects corporate social (ir)responsibility. Strategic Management Journal, 36(August), 1338-1357.

Tihanyi, L., Aguilera, R. V., Heugens, P., van Essen, M., Sauerwald, S., Duran, P., \& Turturea, R. (2019). State ownership and political connections. Journal of Management, 45(6), 2293-2321.

Tzavidis, N., Ranalli, M. G., Salvati, N., Dreassi, E., \& Chambers, R. (2015). Robust small area prediction for counts. Statistical Methods in Medical Research, 24(3), 373-395.

Tzavidis, N., Salvati, N., Schmid, T., Flouri, E., \& Midouhas, E. (2016). Longitudinal analysis of the strengths and difficulties questionnaire scores of the Millennium Cohort Study children in England using $\mathrm{M}$-quantile random-effects regression. Journal of the Royal Statistical Society Series A, 179(2), 427-452.

UNCTAD. (2014). World investment report 2014: Investing in the SDGs: An action plan. World investment report. ISBN: 978-92-1-112873-4.

United Nations. (2011). Guiding principles on business and human rights: Implementing the united nations 'protect, respect and remedy' framework. Ginevra. U. N. Doc. E/CN.4/2006/97.

Vadlamannati, K. C., Janz, N., \& De Soysa, I. (2020). US multinationals and human rights: a theoretical and empirical assessment of extractive vs. non-extractive sectors. Business \& Society. https:// doi.org/10.1177/0007650320928972

Van Buren, H. J., III., Schrempf-Stirling, J., \& Westermann-Behaylo, M. (2021). Business and human trafficking: A social connection and political responsibility model. Business \& Society, 60(2), 341-375.

Vaughan, D. (1999). The dark side of organizations: Mistake, misconduct, and disaster. Annual Review of Sociology, 25, 271-305.

Verbeke, A., Ciravegna, L., Lopez, L. E., \& Kundu, S. K. (2019). Five configurations of opportunism in international market entry. Journal of Management Studies, 56(7), 1287-1313.

Vernon, R. (1977). Storm over the multinationals: The real issues. Harvard University Press.

Vernon, R. (1979). The international aspects of state-owned enterprises. Journal of International Business Studies, 10(3), 7-14.

Wagemann, C., \& Schneider, C. Q. (2010). Standards of good practice inqualitative comparative analysis (QCA) and fuzzy-sets. Comparative Sociology, 9(3), 397-418.
Wettstein, F. (2009). Multinational corporations and global justice. Human rights obligations of a quasi-governmental institution. Stanford University Press.

Wettstein, F. (2010). The duty to protect: Corporate complicity, political responsibility, and human rights advocacy. Journal of Business Ethics, 96(1), 33-47.

Wettstein, F. (2012). CSR and the debate on business and human rights: Bridging the great divide. Business Ethics Quarterly, 22(4), 739-770.

Wettstein, F., Giuliani, E., Santangelo, G. D., \& Stahl, G. K. (2019). International business and human rights: A research agenda. Journal of World Business, 54(1), 54-65.

Whelan, G., \& Muthuri, J. (2017). Chinese state-owned enterprises and human rights: The importance of national and intra-organizational pressures. Business and Society, 56(5), 738-781.

Whiteman, G., \& Cooper, W. H. (2016). Decoupling rape. Academy of Management Discoveries, 2(2), 115-154.

Wright, M. (2008). Corporations and human rights: A survey of the scope and patterns of alleged corporate-related human rights abuse. Corporate Social Responsibility Initiative Working Paper. (44). https://doi.org/10.1093/acprof

Yeager, P. C. (1986). Analyzing corporate offenses: Progress and prospects. Research in Corporate Social Performance and Policy, 8, 93-120.

Yiu, D. W., Xu, Y., \& Wan, W. P. (2014). The deterrence effects of vicarious punishments on corporate financial fraud. Organization Science, 25(5), 1549-1571.

Zahra, S. A., Priem, R. L., \& Rasheed, A. A. (2005). The antecedents and consequences of top management fraud. Journal of Management, 31(6), 803-828.

Zhang, R., Rezaee, Z., \& Zhu, J. (2009). Corporate philanthropic disaster response and ownership type: Evidence from Chinese firms' response to the Sichuan earthquake. Journal of Business Ethics, 91(1), 51-63.

Zyglidopoulos, S., Georgiadis, A. P., Carroll, C. E., \& Siegel, D. S. (2012). Does media attention drive corporate social responsibility? Journal of Business Research, 65(11), 1622-1627.

Zyglidopoulos, S., Williamson, P., \& Symeou, P. C. (2016). The corporate social performance of developing country multinationals. Business Ethics Quarterly, 26(3), 379-406.

Publisher's Note Springer Nature remains neutral with regard to jurisdictional claims in published maps and institutional affiliations. 